Revista do CESP, Belo Horizonte, v.35, n.54, p. 101-115, 2015

\title{
Comissão das lágrimas: o horror é representável?
}

\section{Comissão das lágrimas: is the horror representable?}

\author{
Cid Ottoni Bylaardt \\ Universidade Federal do Ceará \\ cidobyl@gmail.com
}

Resumo: No romance Comissão das lágrimas, de Lobo Antunes, a personagem Cristina encontra-se em uma clínica em Lisboa escrevendo, lembrando os horrores da Comissão das lágrimas, nome que se deu ao massacre dos dissidentes do regime de Agostinho Neto em Angola entre 1977 e 1979. O leitor percebe que a voz de Cristina compõe-se de múltiplas vozes que vão construindo o relato, de maneira fragmentada, embaraçada, descontínua. Este texto tem por objetivo refletir sobre o testemunho, sua constituição, como ele se processa na ficção, na tentativa de articular respostas para algumas questões. É possível representar o irrepresentável, se é que ele existe? É possível testemunhar? Como pode um texto literário servir de testemunho e representação do horror? A hipótese deste texto é que o testemunho se manifestará como um ressoar do evento, uma vibração que o mantém distante da literatura, mas que confere ao inimaginável o estatuto de hiperimaginável.

Palavras-chave: testemunho; ficção; literatura contemporânea.

Abstract: In the novel Comissão das lágrimas, by Lobo Antunes, the character Cristina stays in a psychiatric clinic in Lisbon, writing, remembering the horror of the so-called "Comissão das Lágrimas" ("Commisson of Tears"), the name given to the massacre of the dissidents of Agostinho Neto's political system in Angola from 1977 to 1979. Her voice is made up of multiple voices that build the narrative in a fragmented 
way. This paper aims to think about testimony and its constitution, establishing a dialogue between the novel and the thought of Blanchot, Rancière, Didi-Huberman and Agamben, and trying also to articulate answers to some questions. Is it possible to represent what seems to be unrepresentable? How can a literary text witness and represent horror? This text's hypothesis is that testimony will be expressed as a vibration that keeps it far from literature, but bestows on the unimaginable the status of hyperimaginable.

Keywords: testimony; fiction; contemporary literature.

Recebido em 14 de abril de 2015 Aprovado em 14 de janeiro de 2016

Cristina escreve no silêncio da clínica em Lisboa. As vozes emanadas das árvores, cada folha um discurso desarticulado das outras, lhe dizem coisas graves, que a atormentam, apesar de não fazerem sentido para ela. As injeções parecem trazê-la à normalidade, apaziguase a perturbação e cessam as vozes. Passado o momento de paz, advém novamente a tormenta: "há pretos a correrem em Luanda, camionetas de soldados, tiros, gritos numa ambulância a arder na praia, sob pássaros que se escapavam, e ao terminar de arder nenhum grito...". ${ }^{1}$ Junto com as vozes, uma ordem: "- Tens de matar o teu pai com a faca". ${ }^{2}$ Em certo momento aparece uma data a localizar as lembranças: "... isto em outubro de mil novecentos e setenta e sete, tinha eu cinco anos...". "Isto" parece fazer referência aos horrores da "Comissão das Lágrimas", nome que se deu ao massacre dos dissidentes do regime de Agostinho Neto em Angola entre 1977 e 1979. Para que servem as vozes? Para escrever um livro, talvez. "Se as vozes não voltam não se escreve este livro...". ${ }^{4}$ A matéria do livro não sai de nenhum lugar reconhecível, mas das sementes de avenca, das folhas, "cada folha uma boca" (p. 13). ${ }^{5}$

\footnotetext{
${ }^{1}$ ANTUNES. Comissão das lágrimas, p. 12.

${ }^{2}$ ANTUNES. Comissão das lágrimas, p. 12.

${ }^{3}$ ANTUNES. Comissão das lágrimas, p. 101.

${ }^{4}$ ANTUNES. Comissão das lágrimas, p. 49.

${ }^{5}$ ANTUNES. Comissão das lágrimas, p. 13.
} 
Houve um acontecimento histórico - ele estava lá, e não pode ser apagado. Mas como pode a ficção lidar com tudo isso? O que a literatura e a arte em geral podem/devem, ou não podem/não devem mostrar do horror que emana da história? Afinal, o horror é irrepresentável? Se não, em que condições, de que maneira ele pode ser representado? Afinal, não se pode impedir um escritor de falar de determinado assunto, qualquer que ele seja, assim como não se pode impedir um leitor, ou um crítico, de fazer suas restituições ou apropriações do conteúdo de um romance. Pode haver alguma imagem adequada para expressar o horror dos campos de concentração nazista, ou, mesmo que em escala de repercussão reduzida, o episódio da Comissão das Lágrimas, sem que os extremos do inumano sejam banalizados e se tornem humanos? Por outro lado, a arte não seria culpada de não produzir suficientes imagens do horror, como alerta para o inumano?

Talvez a noção mais rentável nos estudos de literatura - e da arte em geral - seja a de representação. E certamente a mais problemática. O primeiro a discutir a questão no ocidente foi Platão, que colocou os contadores de histórias na sexta categoria entre as almas, porque o que produzem é mentira: praticam a imitação ao invés de buscarem a verdade. Em seguida, Aristóteles regulamenta a mentira, construindo o edifício mimético, que se rege por leis que regulam as relações entre o autor, o discurso e o receptor. A regulamentação da mentira na ficção torna-se a regra séria do que não é sério. Essa concepção aristotélica teve seus desdobramentos durante mais de vinte e quatro séculos, tornando-se uma das grandes perguntas que o pensar sobre a arte produziu na cultura ocidental.

Não se pode simplesmente enunciar a palavra representação e ter acesso imediato a um conceito. Se partirmos do princípio de que, na representação, há uma entidade que está por outra entidade, estabelecemos aí uma relação. Concordar com essa proposição não significa resolver o problema, uma vez que a expressão estar por pode guardar inúmeras possibilidades de relações, incluindo-se aí, por absurdo que possa parecer, a noção de absoluto.

Uma concepção contemporânea na literatura é de que representação não é cópia, nem simulacro, mas uma encarnação, a marca verdadeira de uma presença. Mesmo a noção clássica de romance histórico, com sua pretensa fundamentação referencial, passa a ser substituída pela designação de metaficção historiográfica, a qual encena 
a afirmação e o rompimento dos limites entre ficção e realidade, que rejeita os modelos de representação original e a falsificação da cópia "inautêntica", conforme descrito por Linda Hutcheon em Poética do pós-modernismo. ${ }^{6}$

As imagens que a arte produz do horror atestam sua existência na obra, assim como a existência do horror solicita sua imagem. Pede-se então que a realização da imagem congregue um regime ético e um regime estético. Uma vez apagados os traços do horror, talvez um dos caminhos da arte seja exatamente lembrar o esquecimento, avivar o apagamento pela força da enunciação. Na literatura, as imagens se subordinam às palavras que as dizem, possivelmente porque nos dispensam de ver o que apresentam, ou porque nos fazem ver em excesso. No primeiro caso, o perspectivismo atém os olhares a um determinado ponto de vista, segundo os interesses e as contingências de quem olha, implicando uma cegueira em relação ao que se situa além dos limites do olhar. No segundo caso, a não-circunscrição do olhar pode produzir imagens e desdobramentos em mise-en-abîme. Nunca é demais lembrar a fábula platônica da invenção da escrita, aquela que, segundo seu inventor, tornaria forte a memória dos homens e lhes consolidaria a sabedoria. O deus Thamus, ao analisar a invenção, alertou para o fato de que ela não faria bem à memória, mas apenas às reminiscências dos homens. A escrita propiciar-lhes-ia não a verdade, mas algo semelhante a ela; simularia proporcionar o saber, mas tornaria os homens ignorantes; dar-lhes-ia o vislumbre do saber desprovido de realidade. O crítico da escrita prossegue em suas considerações, acentuando seu caráter errante, desprovida de um pai que a proteja, ela que não pode se defender, entre pessoas que possam ou não compreendê-la, e que não saberão a quem responder. E o que Rancière chama "regime errante da letra órfã cuja legitimidade nenhum pai garante". 7 A escrita vem, assim, desfazer a relação ordenada do fazer, do ver e do dizer, em que os papeis são estabelecidos segundo uma hierarquia de legitimação. Essa heresia foi combatida pelas categorias da inventio (assunto), dispositio (organização das partes) e elocutio (tons e complementos convenientes à dignidade do gênero e à especificidade do assunto) que edificam o templo mimético, ou o que Rancière chama regime representativo das artes.

\footnotetext{
${ }^{6}$ HUTCHEON. Poética do pós-modernismo: história, teoria, ficção, p. 141-162.

${ }^{7}$ RANCIÈRE. Políticas da escrita, p. 9.
} 
É nesse contexto que o pensador francês situa a ideia de representação. Para ele, as noções de irrepresentável e de representável não estão relacionadas ao realismo da representação ou à não-figuração ou, ainda, à intransitividade. Primeiramente, ele recusa a noção de irrepresentável como a impossibilidade de figuração ou de descrição ou de narração como fidelidade aos fatos narrados, descritos, figurados, o que para ele é uma "fábula cômoda". ${ }^{8} \mathrm{O}$ regime representativo não tem como função produzir semelhanças, mas organizar os modos de ver e fazer, subordinando-os a uma regulagem ligada a uma contenção da visão, ao equilíbrio entre efeitos de saber e efeitos de páthos, e a submissão da ficção a critérios de verossimilhança e conveniência. Em oposição ao regime representativo, Rancière opõe o regime estético, que vem desfazer essas obrigações. Tudo então na arte torna-se representável, detonando as fundações do sistema representativo. No novo regime, a palavra não faz ver o que se situa do outro lado de sua transparência, mas manifesta sua opacidade, impondo sua própria presença.

A desestabilização da relação clássica entre sensível e inteligível é mais uma ilimitação dos poderes da representação do que a irrepresentabilidade em si. Para se crer na segunda possibilidade, é necessária, segundo Rancière, uma dupla sub-recepção: uma, referente ao acontecimento; outra, referente à arte em si. Consideremos o evento Auschwitz: como acontecimento seria impensável, como arte seria irrepresentável. O espírito diante desse acontecimento e dessa arte tornase miserável, tomado pelo terror, pelo choque inicial que o transforma em refém do Outro, que, "na tradição ocidental, teria tomado o nome de Judeu". ${ }^{9}$ A responsabilidade de pensar o impensável é transferida ao Outro, cujo testemunho deve ser exterminado: "Deduz-se daí que o extermínio dos judeus está inscrito no projeto de si do pensamento ocidental, na sua vontade de aniquilar a testemunha do Outro, a testemunha do impensável no cerne do pensamento". ${ }^{10}$

No regime estético da arte, a quebra das adequações não impede a representação; antes, amplia suas possibilidades, elimina o irrepresentável ao recusar os limites: "Não há mais limites intrínsecos à representação, não há mais limites para suas possibilidades". ${ }^{11}$

\footnotetext{
${ }^{8}$ RANCIÈRE. O destino das imagens, p. 129.

${ }^{9}$ RANCIÈRE. O destino das imagens, p. 141.

${ }^{10}$ DIDI-HUBERMAN. Imágenes pese a todo, p. 141.

${ }^{11}$ RANCIÈRE. O destino das imagens, p. 147.
} 
Para Didi-Huberman, não se pode mais falar do horror como o indizível, o inimaginável, contra a aposta dos nazistas, os quais contavam com duas impossibilidades para escaparem ilesos em seu projeto sinistro: a imediata desaparição das testemunhas e a certeira irrepresentabilidade do testemunho. A impossibilidade de se acreditar na forma do massacre era a possibilidade de êxito do extermínio: “... as pessoas dirão que os fatos que contais são demasiado monstruosos para serem acreditados". ${ }^{12}$ Pois é exatamente ali onde a imaginação parece naufragar é que se deve perseverar no pensamento. Para Hanna Arendt, citada por Huberman, se não possuímos a verdade, podemos ter acesso a instantes de verdade. ${ }^{13}$ Toda imagem, literária ou não, oscila entre a verdade e a obscuridade. Os próprios testemunhos padecem da desconfiança em sua exatidão: sua relação com a verdade é fragmentária e incompleta, dada a subjetividade de quem relata. Nossa relação com as imagens depende do que solicitamos delas: se pedimos que nos contem tudo, frustrar-nos-emos; se as tentamos compreender, se temos com elas uma certa condescendência em relação a sua inexatidão, sua fragilidade, podemos ter algum diálogo com elas. Certas imagens, ainda que não possam servir como documentos, atuam como enunciação, e quanto mais a enunciação se afirma diante do enunciado, mais nos aproximamos da obra de arte, que garante sua potência na impotência de dizer. ${ }^{14} \mathrm{O}$ que resta, por exemplo, da Comissão das Lágrimas (ou de Auschwitz) está no limite entre os que pereceram e os que se salvaram, é uma lacuna. Um limite inacessível? Não se pode afirmar que tal evento seja inimaginável; ao contrário, só se pode dizer que é imaginável ao extremo, com todas as incompletudes, incertezas, fragmentações da imagem imaginada.

Num capítulo de L'entrétien infini [A conversa infinita] chamado "L'indestructible" ["O indestrutível"], subcapítulo "L'espèce humain" ["A espécie humana"], Maurice Blanchot arrisca uma afirmação que pode ser uma "formule attirant", ${ }^{15}$ mas que "sonne comme une vérité", ${ }^{16}$ embora não seja passível de comprovação em um "savoir déjà vrai”. ${ }^{17} \mathrm{~A}$

\footnotetext{
${ }^{12}$ DIDI-HUBERMAN. Imágenes pese a todo, p. 38.

${ }^{13}$ DIDI-HUBERMAN. Imágenes pese a todo, p. 57.

${ }^{14}$ AGAMBEN, Quel che resta di Auschwitz. L'archivio e il testimone.

15 Trad.: "formula atraente".

16 Trad.: "soa como uma verdade".

17 Trad.: "saber já verdadeiro".
} 
frase é a seguinte: "L'homme est l'indestructible qui peut être détruit". ${ }^{18}$ Neste texto, Blanchot tece considerações sobre o livro de Robert Antelme, L'espèce humain, espécie de desabafo de um sobrevivente de Auschwitz, e relaciona a frase acima à experiência do ex-condenado. $\mathrm{O}$ que poderia ser entendido como um testemunho, na verdade não é mais do que a necessidade de falar para não se sentir totalmente destruído, e é nesse falar sem dizer que Blanchot encontra o significado do livro:

Ce n'est pas, je l'ai dit, ce n'est pas seulement un témoignage sur la réalité d'un camp, ni une relation historique, ni un récit autobiographique. Il est clair que, pour Robert Antelme, et sans doute pour beaucoup d'autres, se raconter, témoigner, c'est ne pas de cela qu'il s'est agi, mais essentiellement parler: em donnant expréssion à quelle parole? Précisement cette parole juste où "Autrui", empêché de se révéler pendant tout le séjour des camps, pouvait seul à la fin être accueilli et entrer dans l'entente humain. ${ }^{19}$

O testemunho, assim, passa a ser uma força enunciativa, contudo uma força dolorosa, sufocante, um movimento extremo, e por mais que, na relação entre dois seres humanos, eles se esforcem por esquecê-la, negá-la ou representá-la, a fórmula estará presente entre eles: "l'homme est l'indestructible, et cela signifie qu'il n'y a pas limite pour la destruction de l'homme". ${ }^{20}$

Quem pode contar a história dos massacrados? Quem pode fazer o relato dos que não têm voz, não têm língua, ou foram eliminados? Primo Levi, em seu depoimento sobre Auschwitz, afirma que os sobreviventes não são as autênticas testemunhas. Eles são os que "por prevaricação,

${ }^{18}$ BLANCHOT. L'éntretien infini, p. 80. Trad.: "O homem é o indestrutível que pode ser destruído."

${ }^{19}$ BLANCHOT. L'éntretien infini, p. 198. Trad.: Não é, eu disse, não é somente um testemunho sobre a realidade de um campo, nem uma relação histórica, nem um relato autobiográfico. É claro que, para Robert Antelme, e sem dúvida para muitos outros, não se trata de narrar-se, testemunhar, trata-se essencialmente de falar: dando expressão a que palavra? Precisamente àquela palavra justa em que "Outrem", impedido de se revelar durante toda a estadia nos campos, poderia somente ao fim ser acolhido e entrar no entendimento humano.

${ }^{20}$ BLANCHOT. L'éntretien infini, p. 200. Trad.: “o homem é o indestrutível, e isso significa que não há limite para a destruição do homem”. 
habilidade ou sorte não tocamos o fundo. Quem o fez, quem fitou a górgona, não voltou para contar, ou voltou mudo". ${ }^{21}$ Cristina, personagem do romance Comissão das lágrimas, com mais de quarenta anos e uma alma abalada, parece tentar relatar em Lisboa os horrores que de alguma forma experimentou entre os cinco e os sete anos de idade em Angola. Poderia ela então ser uma testemunha confiável? Ou então o pai (ou não-pai) de Cristina, o negro que o Deus dos brancos não quis como padre, perturbado pela perseguição das vozes de décadas atrás, como poderia ele testemunhar? O verdadeiro testemunho, portanto, é da ordem da impossibilidade, uma vez que o testemunho absoluto pertence a quem já não pode testemunhar. Os sobreviventes, assim, testemunham pelos outros, pelos que não têm voz. Então qual é a validade, qual é o valor do testemunho dos que testemunham por delegação? A força do testemunho, assim, não está na verdade ou na consistência de uma narrativa, mas na enunciação, no ato de dizer, assim como no ato de não dizer. Não dizer é um grito calado, uma narrativa confusa, impossível de se verificar, é também um grito, um gesto que volta os olhos e ouvidos para o que teria ocorrido, a impossibilidade de se esquecer o que foi feito. Narrar, ficcionalizar é dar voz a outrem, é construir um discurso na falta, na carência, na lacuna. A linguagem dos homens, do mundo de fora do horror não pode ser verdadeira, não consegue nem de longe ser minimamente fiel à experiência do horror. Pode-se pensar aqui então na questão apontada por Agamben, de que o testemunho se dá afinal por um gesto, pela enunciação, por um ter lugar da fala. Então é preciso falar, seja o que for, da maneira que for, este é afinal o testemunho, o que resta. $\mathrm{O}$ resto, o restante, o que mantém de certa forma palpitando o horror. O testemunho, ou sua impossibilidade, se dá na arte pela enunciação.

Ao final de seu comentário sobre o livro L'espèce humaine, de Robert Antelme, Blanchot coloca uma nota de pé-de-página com uma citação de Gerschom Scholem a respeito da relação dos alemães com os judeus após a segunda grande guerra, e faz uma reflexão sobre ela:

“L'abîme qu'ont ouvert entre nous les événements ne saurait être mesuré... Car, em vérité, c'est impossible de se rendre compte de ce qui est arrivé. Le caractère incomprehensible tient à l'essence même du phénomène: impossible de le comprendre parfaitement, c'est-à-dire

${ }^{21}$ LEVI. Os afogados e os sobreviventes, p. 47. 
de l'intégrer à notre conscience." Impossible donc de l'oublier, impossible de s'en souvenir. Impossible, aussi, quand on parle, d'en parler - et finalement, comme il n'y a rien à dire que CET événemnt incomprehensible, c'est la parole seul qui doit reporter sans le dire. ${ }^{22}$

Para Scholem, o ocorrido é incompreensível, não há como assimilá-lo pela consciência. Não há, para Blanchot, como esquecê-lo, assim como não se pode lembrá-lo, resta ao discurso narrá-lo - entretanto, sem dizê-lo. Novamente o inimaginável cede lugar à imagem do grito de horror. As imagens veiculadas pela enunciação obscurecem o evento (que se torna mais de memória - e de esquecimento - do que de história), é algo que não pode ser delimitado ou delineado nem pela linguagem nem pelo saber; é inacessível à subjetividade da representação, às convenções de representatividade, à construção de conceitos, não há como retê-lo ou elucidá-lo. E, em Comissão das lágrimas, a comandar (ou descomandar) isso tudo há um perplexo escritor, o António, que não sabe aonde vai: “... ele que deixara de ser padre há anos, trabalhava num ministério e no entanto, por onde ias António, e no entanto nada, reparem nos olhos ocos de medo..."23

É possível resgatar um grito? Uma cena de horror? O canto de uma mulher sendo dilacerada pela tortura? Como o canto da mulher torturada, a Comissão das Lágrimas é inabordável como evento, é inacessível. Mas não é inimaginável. Tal qual o choro da rapariga

que não parava de cantar enquanto lhe batiam, erguiam-na com um gancho, deixavam-na cair, escutavam-se-lhe as gengivas contra o cimento e ela a cantar com as gengivas, uma bala no ventre e cantava, uma bala no peito e cantava, inclusive sem nariz e sem língua, e o nariz e a língua substituídos por coágulos vermelhos, continuava a cantar,

\footnotetext{
22 BLANCHOT. L'éntretien infini, p. 200. Trad.: "O abismo que os acontecimentos abriram entre nós não pode ser medido... Pois, na verdade, é impossível dar-se conta do que aconteceu. O caráter incompreensível relaciona-se à essência mesma do fenômeno: impossível compreendê-lo perfeitamente, isto é, integrá-lo à nossa consciência." Impossível, portanto, esquecê-lo, impossível lembrá-lo. Impossível, também, quando se fala dele, falar dele - e, finalmente, como não há nada a dizer a não ser esse acontecimento incompreensível, é a palavra apenas que deve narrá-lo sem dizê-lo.

${ }^{23}$ ANTUNES. Comissão das lágrimas, p. 31-32.
} 
julgaram calá-la com um revólver no coração e os arbustos do pátio tremiam, pergunto-me se em lugar dos arbustos eram as minhas mãos que não achavam repouso..."24

Não se trata de contar uma história, não se trata de testemunhar - é preciso falar, falar, falar. A escritura, esse falar, não tem um começo, "Se perguntar como tudo começa nenhuma voz responde...", ${ }^{25}$ não tem passado, não sabe falar das coisas, como o entretemps de Levinas, a suspensão do tempo na sombra da realidade, na indecisão de Cristina, a que tenta relatar: "... e não me lembro disto, invento, não invento, é verdade, ia jurar que não invento, não sei, quer dizer, não estou certa da verdade...". ${ }^{26}$ quem escreve não sabe o que escreve, nada é seguro, nada é confiável.

Quem escreve não tem autoridade sobre os fatos, não os compreende nem os torna compreensíveis. Falar sobre o desconhecido é adentrar um discurso que não exerce nenhuma forma de poder. Cristina não consegue exercer controle sobre a escrita, que se revela dolorosa, difícil: “... que penoso dizer isso, dá a impressão de ser fácil e como a caneta demora, as vozes principiam a rarear...". ${ }^{27}$ Em outro momento a enunciadora parece limitar-se a obedecer mecanicamente ao que lhe ditam, ainda sem controle, ainda sem apreender o sentido da escritura, mas aparentemente sem dor, de forma automática: “... não percebo o que este livro diz, limito-me a escrever o que as coisas ordenam...". ${ }^{28}$

As vozes ditam o livro a Cristina; quando estas se calam, ela se torna um ser "sem substância nem contornos", ${ }^{29}$ de lembranças apagadas, de frases sem sentido, de balbucios incompreensíveis, e "o pavor a crescer". ${ }^{30}$ E Cristina escreve. A escrita é verdadeira? "E se fosse tudo mentira, o que contava mentira, o que o director da Clínica chamava a sua doença mentira..." ${ }^{31}$ A doença então é mentira, a escritura do livro também é mentira? E portanto a escritura é a doença de Cristina? O que é

${ }^{24}$ ANTUNES. Comissão das lágrimas, p. 35.

${ }^{25}$ ANTUNES. Comissão das lágrimas, p. 67.

${ }^{26}$ ANTUNES. Comissão das lágrimas, p. 70.

${ }^{27}$ ANTUNES. Comissão das lágrimas, p. 131.

${ }^{28}$ ANTUNES. Comissão das lágrimas, p. 138.

${ }^{29}$ ANTUNES. Comissão das lágrimas, p. 167.

${ }^{30}$ ANTUNES. Comissão das lágrimas, p. 167.

${ }^{31}$ ANTUNES. Comissão das lágrimas, p. 201. 
então doença, o que é sanidade? O livro então precisa acabar: “... decidi que este livro vai acabar dentro em pouco..." ${ }^{32}$ Que verdade é essa, uma vez que o livro é mentira? Tudo se abala nas indefinições, na instabilidade do discurso: "... a Cristina não existe, há frases que principiam a aparecer, tornando o que digo evidente, mas quando vou escrevê-las somem-se, trago notícias incompletas, não a verdade inteira..."33

O que parece ser uma narrativa é algo próximo a um grito. Mesmo chorar parece ser da ordem da impossibilidade, como diz Alice, mãe: "se ao menos me dissessem como se consegue chorar". ${ }^{34}$ É como o canto de Orfeu, "le langage qui ne repousse pas l'enfer, mais y pénètre, parle au niveau de l'abîme et ainsi lui donne parole, donnant entente à ce qui est sans entente". ${ }^{35}$

Cristina escreve, ela espera que sua mãe responda às perguntas que sua escrita não sabe responder, mas o ferro repousa no apoio metálico e a mãe permanece calada, não à espera da morte, que esta "chega sempre sozinha, simpática, prestável": "- O teu corpo ficou pesado demais para ti eu ajudo". ${ }^{36} \mathrm{O}$ que se escreve é como o que sai da boca, fragmentos de uma verdade misteriosa sem relação com a vida, nem a luz do dia basta, nem para clarear a verdade da escritura e das vozes, nem para revelar o próprio nome dela, "que nome, sob o Cristina, é o meu". ${ }^{37} \mathrm{E}$ a voz pensa na possibilidade de Deus ser interrogado pela Comissão das Lágrimas por conspiração, e ela continua tentando construir um passado, "conforme desenterro defuntos que pilho à minha mãe e ao meu pai porque não sei qual de nós três fala agora". ${ }^{38}$ A voz segue pensando na maldade dos brinquedos, que podiam agredi-la enquanto dormia, lembra um gato bordado em uma almofada que ela liquidou com uma faca para proteger a família, até que comparece a voz do diretor da Clínica e classifica a fala de Cristina dos altos da ciência: "- Faz parte do delírio dela". ${ }^{39}$ E o delírio

\footnotetext{
${ }^{32}$ ANTUNES. Comissão das lágrimas, p. 201.

${ }^{33}$ ANTUNES. Comissão das lágrimas, p. 204.

${ }^{34}$ ANTUNES. Comissão das lágrimas, p. 22.

${ }^{35}$ BLANCHOT. L'éntretien infini, p. 274. Trad. do autor: "a linguagem que não rechaça o inferno, mas penetra nele, fala ao nível do abismo e assim lhe concede a palavra, propiciando acordo àquilo que é sem acordo".

${ }^{36}$ ANTUNES. Comissão das lágrimas, p. 184.

${ }^{37}$ ANTUNES. Comissão das lágrimas, p. 184.

${ }^{38}$ ANTUNES. Comissão das lágrimas, p. 187.

${ }^{39}$ ANTUNES. Comissão das lágrimas, p. 188.
} 
continua com a imagem do pai com uma chave nas costas, que funciona por corda, os horrores da guerra, dos mortos mutilados, do pai a fugir da plantação dos brancos porque se recusava a trabalhar sem paga. Ele mistura o horror da Comissão das Lágrimas com o tempo de seminário e o pavor de ser caçado em Lisboa para responder por seus crimes de comissário interrogador, refere-se à mulher como alguém a quem não pode amar por ser preto e ela branca, ouve a filha a perguntar "qual de nós fala agora", ${ }^{40}$ sugere que ele próprio é criação da filha, "existo na cabeça dela para que consiga existir". ${ }^{41}$ Daí em diante a voz parece pertencer ao pai, que, como integrante da Comissão das Lágrimas, portanto agora com poder, sai em busca dos brancos que o expulsaram da igreja, que o impediram de ser padre porque ele é preto.

O discurso literário é inquieto, contraditório, instável. Interessa-se pelo sentido, pela ausência da coisa, e quer alcançar o sentido nela mesma, por ela mesma (independente da coisa, que agora não tem existência mortal), visando à compreensão do que não se pode compreender. Aqui, Cristina não é apenas uma não-Cristina, mas uma não-Cristina-palavra que se ergue sobre o nada, uma realidade linguística determinada e objetiva. Essa é uma dificuldade e uma mentira, mas a missão do texto literário não pode cumprir-se aí: apenas transpor a realidade de Cristina para a da palavra é pouco. Isso seria uma redução que ignora a impossibilidade de compreensão: a palavra é pouca para o tanto de verdade que contém. O nada luta e trabalha na palavra literária, tornandose a ampliação infinita do sentido, ou seja, o tudo. O lacre se parte, o excesso de sentido, o deslizamento sem fim se desencadeia.

Não obstante, a literatura vai mais além: é a própria impossibilidade da morte. A figuração da morte como impossibilidade, é uma questão fundamental do pensamento blanchotiano: a escrita literária é algo fora do poder, da possibilidade. A morte confere sentido à existência, torna possíveis as coisas, porque possibilita o fim, prerrogativa do reino humano. Fim é objetivo, é busca dentro do finito, do que pode morrer. Ao proclamar a impossibilidade da morte na literatura, Blanchot quer enfatizar o caráter inumano do texto literário, por mais que se considerem as semelhanças que a literatura estabelece em relação ao mundo dos humanos, ou por causa mesmo desse dominó de semelhanças em sua

\footnotetext{
${ }^{40}$ ANTUNES. Comissão das lágrimas, p. 190.

${ }^{41}$ ANTUNES. Comissão das lágrimas, p. 191.
} 
relação especular infinita: a semelhança da semelhança da semelhança... até assemelhar-se a nada. Eis o neutro, o désœuvrement, o que não pode agir verdadeiramente no mundo real.

$\mathrm{O}$ escritor possui o infinito: o que parece abundância é sua grande carência. Carência de limites, de crenças, de regras. Assim, ele é condenado a escrever na falta, na negação, na incerteza, a proferir um discurso que nada diz, que recua diante da existência. A literatura existe para nada dizer, o escritor não fala para dizer algo, a ficção fala para não dizer nada, seu sentido não está na busca do que existe, mas em seu recuo diante da existência.

Decepção, frustração? Fracasso do relato? É possível, mas salvase a literatura, a exibir o vazio do que não existe, a desvelar a ficção, que se veste como se fosse uma espécie de ser, que recebe um nome, narra uma história e uma semelhança com o mundo real. E ergue-se de seus próprios restos, edifica-se de suas próprias ruínas.

$\mathrm{O}$ assunto do romance e seus desdobramentos possibilitaria a construção de uma narrativa que se levantasse de forma digna e inequívoca a respeito de questões políticas e humanas polêmicas, como a alteridade, o respeito às diferenças, a noção de superioridade e inferioridade entre os seres humanos. Isso faria do autor um homem honesto, aquele que escreve as verdades que sua civilização precisa ouvir. Lobo Antunes poderia ter exibido toda sua probidade, mas preferiu embaralhar as verdades que obteve, ou consentiu sua embaralhação, optando por não lhes dar um fim. $\mathrm{O}$ autor não permitiu que sua honesta consciência se transformasse em sua honesta mediocridade, que certamente agradaria em cheio a um grande número de leitores. Segundo Blanchot, "l'œuvre de fiction n'a rien à voir avec l'honêteté: elle triche et n'existe qu'en trichant". ${ }^{42} \mathrm{O}$ romance mora na mentira: se ela o salva, deita a perder a tese, e vice-versa.

Afinal, se representar o horror e testemunhá-lo é possível, desde que haja um acordo sobre o que é representar e testemunhar, a última pergunta é: cabe à arte fazer isso? Para Levinas, poderia - deveria - caber, mas a arte não consegue captar mais do que uma sombra da realidade, ${ }^{43}$ segundo Blanchot, a ficção não representa nada, apenas apresenta os seres

\footnotetext{
${ }^{42}$ BLANCHOT. La part du feu, p. 189. Trad.: "a obra de ficção não tem nada a ver com a honestidade: ela trapaceia e só existe trapaceando".

${ }^{43}$ LEVINAS. Les imprévus d'histoire, p. 107-127.
} 
e objetos, ao invés de tornar-se um sinal deles, "para que os sintamos e para que vivam através da consistência das palavras sua luminosa opacidade de coisa"; ${ }^{44}$ para Rancière, tudo é representável, uma vez que o irrepresentável só existe no sistema representativo, mas é uma representação sem conteúdo determinável, sem "relação estável entre mostração e significação", "45 na opinião de Agamben, a representação e o testemunho do horror (particularmente de Auschwitz) tornam-se uma enunciação cuja possibilidade se sustenta na impossibilidade de dizer; ${ }^{46}$ consoante Didi-Hubermann, a imagem nunca trará a verdade que espera o pesquisador da história, será sempre inadequada, incompleta, fragmentada, estará sempre em falta, mas é a imagem que estimulará a imaginação. ${ }^{47}$

A arte, portanto, se quiser ser arte, jamais poderá ser o testemunho documental, intencional, do horror ou do que quer que seja. Se incluímos no conceito de representação a sombra pálida da realidade, ou se consideramos, como Rancière, que a libertação dos modos codificados de ver e sentir rompe o lacre da representação, podemos reelaborar esse conceito no sentido de reincorporá-lo à arte contemporânea. Nesse caso, o testemunho se manifestará como um ressoar do evento, uma vibração que o mantém distante da literatura, mas que confere ao inimaginável o estatuto de hiperimaginável. A literatura, assim, transforma o evento em outra coisa, que costumamos chamar obra de arte. $\mathrm{O}$ fato histórico não está mais ali, submerso nas formas que a arte elegeu para se manifestar, mas pode ser evocado, de maneira fragmentada, incompleta, infiel, na imaginação de quem se coloca diante da imagem, ainda que o horror jamais possa ser superado em força pela linguagem. Nessa categoria de representável, ou de testemunhável, insere-se o romance Comissão das lágrimas, de António Lobo Antunes.

\footnotetext{
${ }^{44}$ BLANCHOT. La part du feu, p. 80.

${ }^{45}$ RANCIÈRE. $O$ destino das imagens, p. 147.

${ }^{46}$ AGAMBEN. Quel che resta di Auschwitz. L'archivio e il testimone, p. 127-160.

${ }^{47}$ DIDI-HUBERMAN Imágenes pese a todo.
} 


\section{Referências}

AGAMBEN, Giorgio. Quel che resta di Auschwitz. L'archivio e il testimone. Torino: Bollati Boringhieri Editore, 2012

ANTUNES, António Lobo. Comissão das lágrimas. Lisboa: Dom Quixote, 2011.

BLANCHOT, Maurice. L'éntretien infini. Paris: Gallimard, 1969.

BLANCHOT, Maurice. La part du feu. Paris: Gallimard, 2003.

BLANCHOT, Maurice. L'entretien infini. Paris: Gallimard, 2012.

DIDI-HUBERMAN, Georges. Imágenes pese a todo. Trad. Mariana Miracle. Barcelona: Paidós, 2004.

HUTCHEON, Linda. Poética do pós-modernismo: história, teoria, ficção. Trad. Ricardo Cruz. Rio de Janeiro: Imago, 1991.

LEVI, Primo. Os afogados e os sobreviventes. Trad. Luiz Sergio Henriques. Rio de Janeiro: Paz e Terra, 1990.

LEVINAS, Emannuel. Les imprévus d'histoire. Paris: Fata Morgana, 1994.

RANCIÈRE, Jacques. Políticas da escrita. Trad. Raquel Ramalhete. São Paulo: Editora 34, 1995.

RANCIÈRE, Jacques. O destino das imagens. Trad. Mônica Costa Netto. Rio de Janeiro: Contraponto, 2012. 